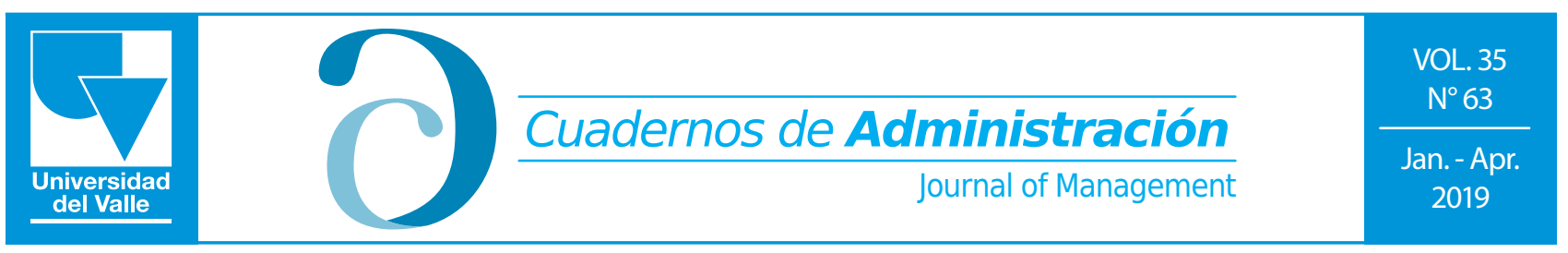

Print ISSN: 0120-4645 / E-ISSN: 2256-5078 / Short name: cuad.adm. / Pages: 15-25

Faculty if Administration Sciences / Universidad del Valle / Cali - Colombia

\title{
Knowledge management from the organizational culture in call centers in Manizales
}

\author{
Gestión de conocimiento desde la cultura organizacional en centros \\ de llamadas de Manizales
}

\author{
Gestion des connaissances issues de la culture organisationnelle dans \\ les centres d'appels de Manizales
}

\begin{abstract}
Carlos Eduardo Marulanda Echeverry ${ }^{1}$
Professor, Department of Administration, Faculty of Administration, Universidad Nacional de Colombia, Manizales, Colombia. ORCID ID: https://orcid.org/0000-0002-6287-9386. e-mail: cemarulandae@unal.edu.co
\end{abstract}

Oscar Mauricio Bedoya Herrera²

Professor, Department of Systems and Informatics, Universidad de Caldas, Manizales, Colombia ORCID ID: https://orcid.org/0000-0002-6757-3327. e-mail: oscar.bedoya@ucaldas.edu.co

Andrés Paolo Castaño Vélez ${ }^{3}$

Professor, Department of Systems and Informatics, Universidad de Caldas, Manizales, Colombia ORCID ID: https://orcid.org/0000-0002-4767-0963. e-mail: andres,castano@ucaldas.edu.co

Article of Scientific and Technological Research, PUBLINDEX-COLCIENCIAS classification

Submitted: 26/08/2018

Reviewed: 09/10/2018

Accepted: 14/12/2018

Core topic: Administration and Organizations

JEL classification: M14, M16

\section{Abstract}

DOI: https://doi.org/10.25100/cdea.v35i63.6811

Knowledge management is currently considered a key factor for organizational development, even more so with the constant competitive dynamics of companies, which see in knowledge a fundamental potential to improve productivity. In this sense, its assessment is key, but considering the culture as a conditioning variable to the development of this procedure nonetheless. Although several studies have addressed the subject, there has been insufficient research into the call center services companies in Colombia. The research results presented herein are part of a qualitative research project with descriptive and correlational studies on knowledge management in BPO companies in the city of Manizales, Colombia. An assessment of the knowledge management categories and organizational culture was made, based on the adaptation of a knowledge management assessment model, of which 312 observations were made. It is concluded that organizational culture is statistically significant for knowledge management.

Keywords: Knowledge management, Organizational culture, BPO.

Industrial Engineer, PhD in Industrial Engineering and Organizations, Universidad Nacional de Colombia, Manizales headquarters.

2 Systems Engineer, Universidad autónoma de Manizales, Master in Systems and Computing, Universidad de Caldas.

3 Electrician Engineer, Universidad Nacional de Colombia, PhD in Computer Engineering, Universidad Pontifica de Salamanca, Spain. 


\section{Resumen}

La gestión de conocimiento es considerada en la actualidad un factor clave para el desarrollo organizacional, más aún con las constantes dinámicas competitivas de las empresas, la cuales, ven en el conocimiento un potencial fundamental para mejorar la productividad; en este sentido es fundamental su valoración, pero considerando la cultura organizacional como una variable condicionante al desarrollo de esta gestión. Aunque se han hecho diversos estudios sobre el tema, no se ha indagado lo suficiente en las empresas dedicadas a los servicios de centros de llamadas en Colombia. Los resultados de investigación presentados en este artículo son parte de un proyecto de investigación cualitativo con estudios de tipo descriptivo y correlacional, sobre la gestión de conocimiento en empresas BPO de la ciudad de Manizales Colombia. Se hizo una valoración de las categorías gestión de conocimiento y cultura organizacional, a partir de la adaptación de un modelo de evaluación de gestión de conocimiento del cual se hicieron 312 observaciones. Se concluye que la cultura organizacional es estadísticamente significativa para la gestión de conocimiento.

Palabras clave: Gestión de conocimiento, Cultura organizacional, BPO.

\section{Résumé}

La gestion des connaissances est aujourd'hui considérée comme un facteur clé du développement organisationnel, d'autant plus que la dynamique concurrentielle constante des entreprises, qui voient dans la connaissance un potentiel fondamental pour améliorer la productivité; en ce sens, son évaluation est fondamentale, mais en considérant la culture organisationnelle comme une variable conditionnelle au développement de cette gestion. Bien qu'il y ait eu plusieurs études sur le sujet, il n'y a pas eu assez de recherches dans les entreprises qui se consacrent aux services des centres d'appels en Colombie. Les résultats de recherche présentés dans cet article font partie d'un projet de recherche qualitative avec des études descriptives et corrélationnelles sur la gestion des connaissances dans les entreprises d'externalisation des processus d'affaires (BPO) de la ville de Manizales en Colombie. Une évaluation des catégories, gestion des connaissances et culture organisationnelle a été réalisée sur la base de l'adaptation d'un modèle d'évaluation de la gestion des connaissances à partir duquel 312 observations ont été faites. On en conclut que la culture organisationnelle est statistiquement significative pour la gestion des connaissances.

Mots-clés: Gestion des connaissances, Culture organisationnelle, (BPO).

\section{Introduction}

The permanent changes in today's world make it necessary for companies to take positions and generate developments that allow them to face new dynamics from their potential, their tangible and intangible resources and their human talent, among others, without forgetting the progress of the work context.

From these situations, itbecomes necessary to develop innovation schemes within the framework of Knowledge Management (KM), which has become the hope of companies to advance and improve permanently on the path to success, represented in greater profitability and revenue.

However, KM can become a reality from many perspectives, one of them related to organizational culture, which makes it possible to experience day-to-day the possibility of sharing, transferring, applying and creating knowledge that results in the possibility of companies moving on.

In the case of BPO (Business process outsourcing) companies, $\mathrm{KM}$ is vital especially considering that the knowledge from information is the core operation and the main source of resources, hence the importance of research that supports the findings presented in this paper concerning call center companies, which at the moment are among the companies that generate the most direct jobs in the city of Manizales, department of Caldas, Colombia.

Then, it is from the adaptation of the KM assessment model by Marulanda, Giraldo, and Serna (2015), that BPO companies dedicated like call centers were evaluated and from this we present the findings related to organizational culture and $\mathrm{KM}$, which will undoubtedly serve as a contribution to the various undergoing processes within these companies in pursuance of their benefit in the short, medium and long term.

The research objective on which the results put forward herein are based is to establish the relationship between knowledge management and organizational culture.

\subsection{Knowledge management}

Nowadays, knowledge, innovation and creativity are widely recognized as the most crucial competitive factors capable of 
substantially supporting and foster a company's adaptation, survival and outstanding performance (Sigala and Chalkiti, 2015). There is a reciprocal relationship between these three concepts, since an organization's ability to generate ideas and innovate is based on learning, broadening its knowledge base and its people sharing their knowledge.

In a context of continuous change and uncertainty, it is critical for companies to develop skills to create and acquire knowledge, learn, share what has been learned and put it into practice. Administrative knowledge is associated with business success and the ability of a company to adapt to environmental changes and challenges. Due to knowledge, companies can innovate, create organizational routines, grow, be sustainable and gain competitive advantages (Calvo-Mora, Navarro-García, Rey-Moreno, and Periañez-Cristobal, 2016).

According to Chidambaranathan and Rani (2015), knowledge is widely recognized as a competitive advantage and a growing number of organizations are incorporating $\mathrm{KM}$ as a core strategy to improve organizational effectiveness. Knowledge is generally distributed within an organization tacitly and explicitly. Tacit knowledge is what lies in the minds of employees within an organization, and is the most critical factor for its success. Explicit knowledge is freely available in print as well as electronic media within an organization and is easily accessible.

Jasinskas, Svagzdiene, and Simanavicius (2015) and Rabeea, Nassar, and Khalid (2017) explain that knowledge is very important to obtain competitive advantages in the activity of a company. Knowledge is an important source and probably one of the most valuable with regards to competitive capacity. The ability of KM to influence a company's competitive capacity depends on how successfully the company applies different types of knowledge. Companies must take advantage of the knowledge of their employees, develop, organize and apply it in the creation of new products, innovations and business decisions.

KM improves organizational effectiveness by integrating people, processes, and technology and is a process that helps organizations find, select, organize, disseminate and transfer important information and experience needed for activities such as problem-solving, dynamic learning, strategic planning and decision making. $\mathrm{KM}$ is the process of acquiring, storing, sharing, creating and using knowledge for process improvement from intensive teamwork and effective knowledge sharing among individuals (Lee, Shiue, and Chen, 2016).

Likewise, Cahyaningsih, Sensuse, Arymurthy, and Wibowo (2017), conclude that $\mathrm{KM}$ is a strategic issue in organizations capable of improving organizational performance. KM can narrow the knowledge gap between people and the organization, and improve organizational learning for it to achieve its goals with collaboration and cooperation between employees and the organization, and can improve the performance of human capital management, among others.

There is a consensus that the $\mathrm{KM}$ is a structured approach to creating, coding, and using, collecting, exchanging, measuring and retaining knowledge to respond to environmental challenges and create additional value. To be valuable to a company, KM should lead to changes in behavior and the development of new ideas, processes, practices and policies. Although there are several models that explain KM processes, most of them comprise the following five generic processes: acquisition, generation and creation, coding, storage, exchange, transfer and utilization of knowledge.

In this sense, Donate and Sánchez (2015) explain that KM is used to develop and implement initiatives that improve the efficiency of the processes of a business, increase the productivity and quality of its services, and find new solutions and products for its customers. Therefore, ideal conditions should be set to promote and optimize the use of KM practices such as human resources management, an appropriate corporate culture, technology implementation and organizational structures. $\mathrm{KM}$ is a set of activities, initiatives and strategies that companies use to generate, store, transfer and apply knowledge to improve organizational performance.

In addition, Lendzion (2015), states that, nowadays, knowledge is a key resource for 
organizations. It is a basic element of the competences of people, who execute processes related to identifying, creating, obtaining, purifying, protecting and transferring knowledge, which is directly related to the shape of the social work environment, the behavior of people, the processes of individual thinking and in particular health, both physical and intellectual, a hierarchy of human values, norms and attitudes that manage their behavior, loyalty and mutual trust, level of collectivity and innovation, among others.

$\mathrm{KM}$ is a process of creating and using knowledge to improve the effectiveness of corporate activities; it promotes a complex attitude to identify, manage and share all information resources, such as databases, documents, policies and procedures but most importantly, experience and skills not expressed as explicitly as the employee has it; in addition to an adequate technical and organizational infrastructure that enables the exchange of knowledge, with a choice of the right information technology (Koloniari and Fassoulis, 2017). In this line of thinking, Tongsamsi and Tongsamsi (2017) argue that $\mathrm{KM}$ requires a process of collecting and exchanging the knowledge of the individual, applying practices of a learning organization (Alharithy, 2015).

Hussain, Konar, and Ali (2016) identified personality, willingness to share and organizational commitment as determining factors in individual participation for the exchange of knowledge within an organization. $\mathrm{KM}$ is a social process, where the influence of social and cultural factors that allow integrating the knowledge, skills and experience of employees should be taken into account in order to obtain a better competitive advantage and effective administrative practices in daily operations. Just as technologies, motivations and culture affect knowledge-sharing behaviors. Within this framework, Alaarj, Abidin-Mohamed, and Ahmad, (2016), explain that KM requires a culture of trust among the members of an organization to share knowledge.

\subsection{Organizational culture}

Sensuse, Cahyaningsih, and Catur (2015) sustain that organizational culture reflects as a norm and belief, as a behavioral guide for all members of the organization. Therefore, organizational culture is influenced by the mindset and individual culture established at each level of the organization and becomes a challenge to encourage efficiency. Organizational culture is generated from management to all levels to encourage knowledge sharing and interaction among members of the organization; in fact, organizational culture has some influences on knowledge management through values and behavior reflected in KM.

From a simple perspective, Bowers, Hall, and Srinivasan (2017) conclude that organizational culture is a set of basic and tacit assumptions shared by a group of people about what the world is and should be. These tacit assumptions determine perceptions, thoughts, feelings and to some extent, their manifest behavior that drives their actions and responses.

Along this line, Sánchez, Carrasco, Danvila, and Sastre (2016), sustain that organizational culture has traditionally been considered one of the most important intangible strategies in the development of competitive advantages, assuming that norms of behavior are created from beliefs and expectations, which shape the behaviors of individuals and groups within an organization. Culture can be understood as a resource closely tied to the rest of the company's resources, as well as a management mechanism that can be a competitive advantage.

However, Klimas (2016) defines organizational culture as a driving force for competitiveness as it influences intraorganizational development, its effectiveness and financial performance. It is understood as a set of values, beliefs and assumptions and perceptions shared by the members of organizations, which enables flexibility, innovation, effectiveness, organizational development and performance. It is an intangible, organizational and strategic resource, directly related to the overall performance of the organization.

Likewise, Erhardt, Martin-Rios, and Heckscher (2016) define organizational culture as a complex system of shared values, which guides the actions of the members of an organization. Values such 
as camaraderie, creativity, performance and efficiency work as the foundation of the organization's culture, which create an identity and differentiate it from competitors. Fundamental values such as risk-taking and attention to detail constitute collective knowledge (i.e. understanding) within an organization that is rooted in principles, code of conduct, beliefs or philosophy of how the organization operates.

To complement Lee, Raschke, and Louis (2016), argue that organizational culture is a complex set of values, norms and symbols that define how a company its conducts business. This culture encourages employees to accept the goals and values of the organization's leaders while promoting a sense of belonging. Culture emphasizes a human affiliation in a flexible structure, an internal focus on cohesion and morale, and the development of human resources to build team spirit and values the roles, rules and regulations imposed, bringing about clarity, transparency and stability to workers, thus encouraging efficiency, punctuality and proper functioning.

Likewise, Ahmady, Nikooravesh, and Mehrpour (2016) express that organizational culture can be a powerful resource of common identity, purpose and flexible guidelines. Its effect on people has been so strong that the behavior, feelings, perceptions, and attitudes of the members of an organization can be predicted. To strengthen organizational culture as support to knowledge management, the following should be considered:

- Changing the attitude and vision of the authorities towards the role and position of knowledge.

- Using tools for employees who perform well, innovative and risky.

- Implementing strategic programs for knowledge management.

- Building confidence in the organization so that employees do not feel danger in transferring their work skills to others.

- Encouraging knowledge-based employees to transfer knowledge to others and set up the processes in which the knowledge of rivals could be used.
- $\quad$ Strengthening a supportive and friendly environment in the organization.

In addition, Oyemomi, Liu, Neaga, Chen, and Nakpodia (2017), sustain that the development of the organizational culture serves several purposes. Firstly, it conveys a sense of identity to the members of the organization. Secondly, it facilitates the generation of commitment. Thirdly, culture improves the stability of the organization. Fourth, culture serves as a sensory device that can guide and shape behavior (Valmohammadi and Roshanzamir, 2015).

On the other hand, SzczepańskaWoszczyna (2015), conclude that culture is very important for leading organizations to success; provided that all the staff of the organizations is fully engaged in this matter. Organizational culture is the element that unites employees' objectives to achieve subsequent levels of excellence while reflecting the image of the organization. Organizational culture can be a favorable element for the development of innovative activities. Values, norms, and beliefs that play a role in creativity and innovation in organizations can support or inhibit creativity and innovation, depending on how they influence the behavior of individuals and groups. In general, leaders also have a powerful source of influence on employees' work behaviors (Hussein, Omar, Noordin, and Ishak, 2016).

Lastly, Lee, et al. (2016) asserts that organizational culture influences the way employees think, act and respond to process improvement, and affects the scope of collaboration between employees while improvement work is underway. In addition, it influences the will and behavior of employees in terms of sharing knowledge.

\subsection{Knowledge management assessment model}

For the research purposes, the knowledge management assessment model of Marulanda et al (2015) was used,which is defined from an integral and holistic concept and considers the following: it is based on three dimensions, with their respective categories, such as infrastructure, which contains the categories 
Figure 1. KM Assessment Model

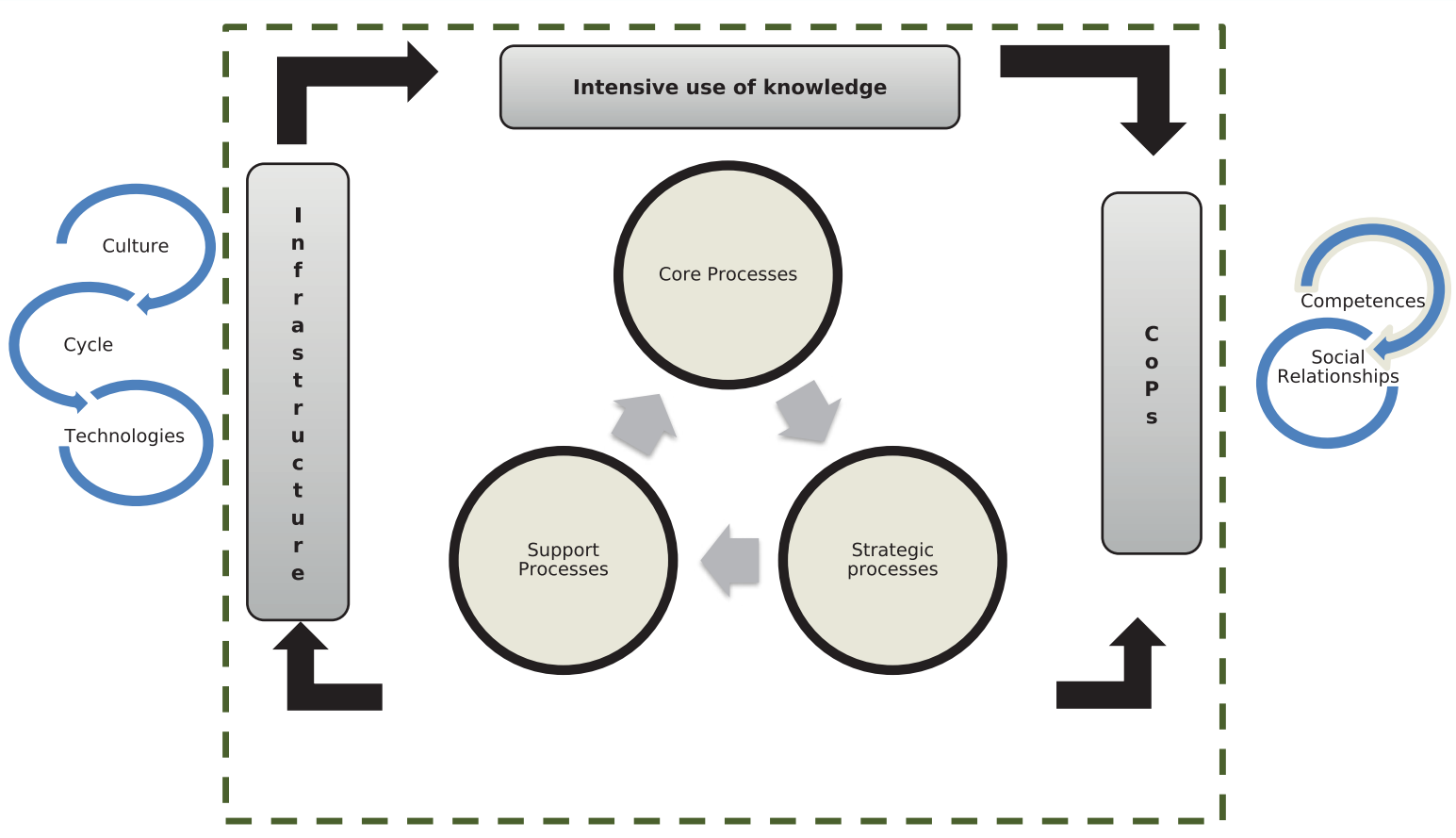

Source: Adapted from Marulanda et al. (2015).

organizational culture, Information and Communications Technologies (ICT) and knowledge life cycle; Communities of Practice (COP), which contains the categories personal competencies, adaptation, COPs techniques and social relations; and the category intensive use of knowledge, which includes the categories core processes, strategic processes and support processes. This whole set for the purpose of meeting the needs of stakeholders, through the services that can be offered, as can be seen in Figure 1.

\section{Methodology}

For the case of the findings presented in this paper, we did a qualitative research with two types of studies, a descriptive one and a correlational one, which, according to Mejía (2004), through meanings and from a holistic perspective seeks to understand the set of interrelated traits that characterize a certain phenomenon.

\subsection{Sampling}

A survey was applied to the three largest BPO call center companies in the city of
Manizales, Colombia, and 312 observations were obtained (within the framework of the concept of statistical convenience and given the difficulties in obtaining responses to surveys). For the structuring of the questionnaire, Likert-type scale questions were asked, which were graded from 1 to 5 , where 1 means disagree or not done, 2 means partially done, 3 done at intervals, 4 done regularly and 5 fully done. See annex.

\subsection{Data Analysis}

Based on the developments by Hair, Anderson, Tatham, and Black (2007), a correlation analysis was applied, which involves simultaneously correlating several dependent metric variables and several independent metric variables. Ideal values of correlation results above 0.5 .

\subsection{Categories and variables assessed}

In the case of the findings presented in this paper, the following categories were assessed:

KM Life Cycle: understood as a 
continuous process that makes it possible for knowledge to be transversal to each and every organizational process. In this sense, the following variables were considered: identifying, generating, retaining, sharing and applying knowledge.

Organizational culture: understood as the set of customs, rites, norms and ways of acting of an organization, which serves as a mediator of the relationship between staff and organizational knowledge, and determines that knowledge belongs to the organization and remains under the control of individuals and groups. In this sense, the following variables were considered: people, narrative and workplace.

\section{Results and discussion}

Below are the results of the categories and variables evaluated from the life cycle of the model that makes it possible to assess knowledge management (identifying (ID), generating (GEN), retaining (RET), sharing (COM) and applying (APL) knowledge) and from organizational culture (people (PER), narrative (NAR) and workplace (SIT)) in the companies BPO call center of the City of Manizales. The assessment was made based on the survey that supports the KM assessment model and the results can be seen in Figure 2.

Figure 2. Knowledge management

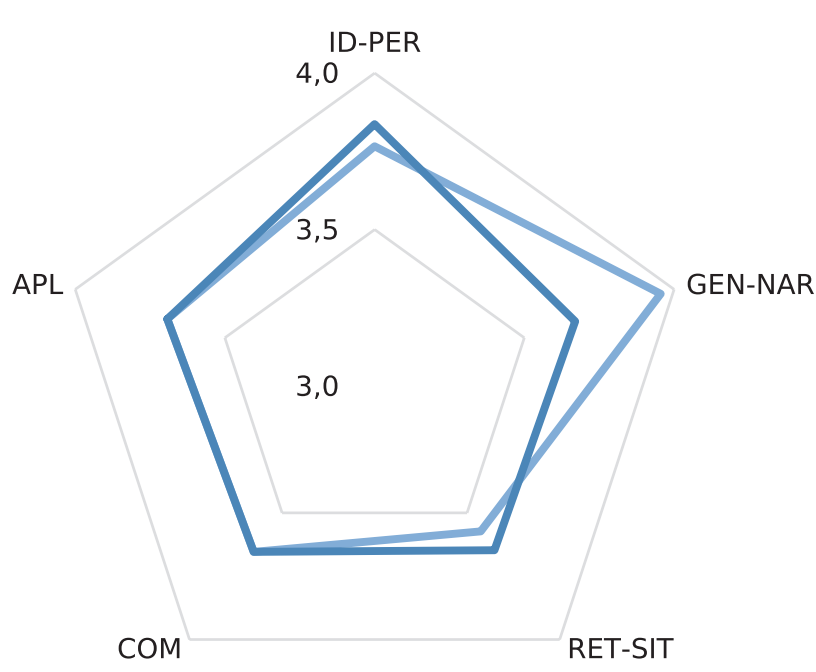

Source: Authors' own elaboration.
Figure 2 highlights the following results regarding the life cycle of knowledge: generating knowledge with a rating of 4 out of 5, which shows the important contribution of these companies to allow the generation of knowledge, while a little more than 3.0 in the retention of knowledge, which contrasts the highest valuation. Regarding organizational culture, the variables evaluated have a rating of 3.5 in terms of narratives, people and workplaces. This assessment indicates that knowledge generation is done regularly, while knowledge retention occurs at intervals, a situation that needs to be improved given the direct relationship between retaining and generating knowledge; as well as improving organizational culture-related variables.

However, it is essential to outline the relationship between culture and the life cycle of KM, given the importance and effect of one and the other. To that end, a correlation was made to establish the level of significance between these categories and variables. The results of this correlation can be seen in Table 1.

The results of the correlation assessment show that there is a significant correlation between organizational culture and KM. These results run along the same lines of Chih-Hsing (2018), who found that KM relies on resources, networks, and people to exploit market opportunities and achieve better performance. Similarly, Wei and Miraglia (2017) found that the ability to systematically create, manage and harness knowledge assets can contribute substantially to the achievement of long-term goals within the framework of the organizational culture that influences people and teams in organizations, with a relationship existing between organizational culture and KM.

Likewise, Ferro, Severo, and Maia (2018) concluded that $\mathrm{KM}$ aims at storing and providing the knowledge generated with the facilitation of the organization's culture; knowledge is developed by individuals based on their collective daily work and is part of the interaction between people inside and outside the organization. MorgulisYakushev, Yildiz, and Fey (2018) concluded that for knowledge to flow it is necessary that organizational structures have a higher level of adaptation from organizational culture. 


\begin{tabular}{|c|c|c|c|c|c|c|c|c|}
\hline \multicolumn{9}{|c|}{ Correlations } \\
\hline & ID & GEN & RET & $\mathrm{COM}$ & APL & PER & NARR & PLACE \\
\hline \multicolumn{9}{|c|}{1} \\
\hline ID & 1 & & & & & & & \\
\hline GEN &, $438 * *$ & 1 & & & & & & \\
\hline RET &, $342 * *$ &, $321 * *$ & 1 & & & & & \\
\hline COM &, $306 * *$ &, $479 * *$ &, $396 * *$ & 1 & & & & \\
\hline APL &, $329 * *$ & $245^{* *}$ &, $412 * *$ &, $184^{* *}$ & 1 & & & \\
\hline PER &, $413^{* *}$ &, $324 * *$ & $413^{* *}$ &, $337 * *$ &, $344^{* *}$ & 1 & & \\
\hline NARR &, $316 * *$ &, $308 * *$ &, $353 * *$ &, $342 * *$ & ,333** &, $528 * *$ & 1 & \\
\hline PLACE &, $437 * *$ & ,256** & $414^{* *}$ &, $333^{* *}$ &, $503 * *$ & ,379** &, $462 * *$ & 1 \\
\hline \multicolumn{9}{|c|}{ **. The correlation is significant at level 0.01 ( 2 ends). } \\
\hline \multicolumn{9}{|c|}{ Source: Authors' own elaboration } \\
\hline
\end{tabular}

Di-Iorio and Rossi (2018), argue that knowledge workers in organizations often participate in adaptive, defined and applied business processes, within the framework of processes and practices committed to achieving the objectives of the organization, within these lies the exploitation of knowledge. Chidambaranathan and Rani (2015) examined the relationships between knowledge management and organizational culture using the competency values framework and found a positive correlation between the two.

Trivellas, Akrivouli, Tsifora, and Tsoutsa (2015) assert that a series of empirical studies recognize the crucial impact of knowledge exchange and organizational culture. KM aims to create work-related knowledge among members of the organization, taking into account the willingness of employees to share knowledge with others and their behaviors through which they exchange relevant information with their colleagues. Shahzad, Xiu, and Shahbaz (2017) concluded that organizational culture is highly significant and plays a vital role in the success of $\mathrm{KM}$ in an organization, and is highly correlated with employee satisfaction and performance. Warrick (2017) concluded that there are close ties between culture, organizational performance, behavior and the attitudes of people in organizations and KM.

\section{Conclusions}

KM is today a key factor for the development of any organization, in this case, the BPO call center companies in the city of Manizales, which according to the assessment are aimed at a better horizon, given the importance they have given to this issue.

The qualification shows that strategies, plans, and activities that make employees feel like part of the organizational culture are under implementation, which enables knowledge contributing and sharing, a vital resource for a company of this type of services

Organizational culture is a key factor for the development of an appropriate KM strategy and it is essential to understand the importance of this strategy in business development; the correlation test mathematically established the direct relationship between both categories and it is clear that not only a technological or process look should be held on the development of $\mathrm{KM}$, organizational culture is vital for this purpose.

More in-depth studies are needed on the retention of knowledge, workplaces and knowledge communication by employees of the evaluated companies. 


\section{Acknowledgements}

This work is part of the results of the research project entitled "The transfer of knowledge in the research centers of the coffee triangle of Colombia", which was registered and funded by the Research Directorate of the National Universidad Nacional de Colombia, Manizales headquarters, with Hermes code 35721.

\section{References}

Ahmady, G., Nikooravesh, A., \& Mehrpour, M. (2016). Effect of organizational culture on knowledge management based on Denison model. Procedia - Social and Behavioral Sciences, (230), 387-395. doi:doi: 10.1016/j. sbspro.2016.09.049

Alaarj, S., Abidin-Mohamed, Z., \& Ahmad, U. (2016). Mediating Role of Trust on the Effects of Knowledge Management Capabilities on Organizational Performance. Procedia - Social and Behavioral Sciences, (235), 729-738. doi:doi: 10.1016/j.sbspro.2016.11.074

Alharithy, M. (2015). Knowledge Management Process in several organizations: Analytical Study of modeling and several processes. Procedia Computer Science, (65), 726-733. doi:doi: 10.1016/j.procs.2015.09.017

Bowers, M., Hall, R., \& Srinivasan, M. (2017). Organizational culture and leadership style: The missing combination for selecting the right leader for effective crisis management. Business Horizons, (60), 551-563. doi:http:// dx.doi.org/10.1016/j.bushor.2017.04.001

Cahyaningsih, E., Sensuse, D., Arymurthy, A., \& Wibowo, W. (2017). NUSANTARA: A New Model of Knowledge Management in Government Human Capital Management. Procedia Computer Science, (124), 61-68. doi:10.1016/j. procs.2017.12.130

Calvo-Mora, A., Navarro-García, A., Rey-Moreno, M., \& Periañez-Cristobal, R. (2016). Excellence management practices, knowledge management and key business results in large organisations and SMEs: A multi-group analysis. European Management Journal, (34), 661-673. doi:http:// dx.doi.org/10.1016/j.emj.2016.06.005

Chidambaranathan, K., \& Rani, S. (2015). Knowledge management and organizational culture in higher educational libraries in Qatar: An empirical study. Library \& Information Science Research, (37), 363-369. doi:http:// dx.doi.org/10.1016/j.lisr.2015.11.002
Chih-Hsing, S. (2018). Examining social capital, organizational learning and knowledge transfer in cultural and creative industries of practice. Tourism Management, (64), 258-270. doi:http:// dx.doi.org/10.1016/j.tourman.2017.09.001

Di-Iorio, A., \& Rossi, D. (2018). Capturing and managing knowledge using social software and semantic web technologies. Information Sciences, (432), 1-21. doi:https://doi. org/10.1016/j.ins.2017.12.009

Donate, M., \& Sánchez, J. (2015). The role of knowledge-oriented leadership in knowledge management practices and innovation. Journal of Business Research, (68), 360-370. doi:http:// dx.doi.org/10.1016/j.jbusres.2014.06.022

Erhardt, N., Martin-Rios, C., \& Heckscher, C. (2016). Am I doing the right thing? Unpacking workplace rituals asmechanisms for strong organizational culture. International Journal of Hospitality Management, (59), 31-41. doi:http:// dx.doi.org/10.1016/j.ijhm.2016.08.006

Ferro, J., Severo, E., \& Maia, C. (2018). The influence of entrepreneurial, market, knowledge management orientations on cleaner production and the sustainable competitive advantage. Journal of Cleaner Production, (174), 1653-1663. doi:https://doi.org/10.1016/j.jclepro.2017.11.074

Hair, J., Anderson, R., Tatham, R., y Black, W. (2007). Análisis multivariante. Madrid, España: Pearson.

Hussain, K., Konar, R., \& Ali, F. (2016). Measuring Service Innovation Performance through Team Culture and Knowledge Sharing Behaviour in Hotel Services: A PLS Approach. Procedia Social and Behavioral Sciences, (224), 35-43. doi:doi: 10.1016/j.sbspro.2016.05.397

Hussein, N., Omar, S., Noordin, F., \& Ishak, N. (2016). Learning Organization Culture, Organizational Performanceand Organizational Innovativeness in a Public Institution of Higher Education in Malaysia: A Preliminary Study. Procedia Economics and Finance, (37), 512-519. doi:doi: 10.1016/S2212-5671(16)30159-9

Jasinskas, E., Svagzdiene, B., \& Simanavicius, A. (2015). The Influence Of Knowledge Management On The Competitive Ability Of Lithuanian Enterprises. Procedia - Social and Behavioral Sciences, (191), 2469-2475. doi:doi: 10.1016/j.sbspro.2015.04.305

Klimas, P. (2016). Organizational culture and coopetition: An exploratory study of the features, models and role in the Polish Aviation Industry. Industrial Marketing Management, 53, 91-102. doi:http://dx.doi.org/10.1016/j. indmarman.2015.11.012 
Koloniari, M., \& Fassoulis, K. (2017). Knowledge Management Perceptions in Academic Libraries. The Journal of Academic Librarianship, (43), 135-142. doi:http://dx.doi.org/10.1016/j. acalib.2016.11.006

Lee, J.-C., Shiue, Y.-C., \& Chen, C.-Y. (2016). Examining the impacts of organizational culture and top management support of knowledge sharing on the success of software process improvement. Computers in Human Behavior, (54), 462-474. doi:http://dx.doi.org/10.1016/j. chb.2015.08.030

Lee, M., Raschke, R., \& Louis, R. (2016). Exploiting organizational culture: Configurations for value through knowledge worker's motivation. Journal of Business Research, (69), 5442-5447. doi:http:// dx.doi.org/10.1016/j.jbusres.2016.04.152

Lendzion, J. (2015). Human resources management in the system of organizational knowledge management. Procedia Manufacturing, (3), 674680. doi:doi: 10.1016/j.promfg.2015.07.303

Marulanda E., C. E., Giraldo G., J. A., \& Serna G., H. M. (2015). Modelo de evaluación de gestión del conocimiento para las pymes del sector de tecnologías de la Información. AD-minister (26). http://dx.doi.org/10.17230/ad-minister.26.2

Mejía Navarrete, J. (2004). Sobre la investigación cualitativa. Nuevos conceptos y campos de desarrollo. Investigaciones Sociales, 8(13), 277-299.

Morgulis-Yakushev, S., Yildiz, E., \& Fey, C. (2018). When same is (not) the aim: A treatise on organizational cultural fit and knowledge transfer. Journal of World Business, (53), 151-163. doi:http://dx.doi.org/10.1016/j.jwb.2017.09.002

Oyemomi, O., Liu, S., Neaga, I., Chen, H., \& Nakpodia, F. (2017). How cultural impact on knowledge sharing contributes to organizational performance: Using the fsQCA approach. Journal of Business Research, (94), 313-319. doi: https://doi.org/10.1016/j. jbusres.2018.02.027

Rabeea, O., Nassar, I., \& Khalid, M. (2017). Knowledge management processes and sustainable competitive advantage: An empirical examination in private universities. Journal of Business Research, (94), 320-334. doi: https://doi.org/10.1016/j.jbusres.2018.02.013

Sánchez, G., Carrasco, A., Danvila, I., \& Sastre, M. (2016). Organizational culture and family business: A configurational approach. European
Journal of Family Business, 6, 99-107. doi:http:// dx.doi.org/10.1016/j.ejfb.2017.05.002

Sensuse, D., Cahyaningsih, E., \& Catur, W. (2015). Knowledge Management: Organizational Culture in Indonesian Government Human Capital Management. Procedia Computer Science, (72), 485-494. doi:doi: 10.1016/j. procs.2015.12.130

Shahzad, F., Xiu, G., \& Shahbaz, M. (2017). Organizational culture and innovation performance in Pakistan's software industry. Technology in Society, (51), 66-73. doi: http:// dx.doi.org/10.1016/j.techsoc.2017.08.002

Sigala, M., \& Chalkiti, K. (2015). Knowledge management, social media and employee creativity. International Journal of Hospitality Management, (45), 44-58. doi:http://dx.doi. org/10.1016/j.ijhm.2014.11.003

Szczepańska-Woszczyna, K. (2015). Leadership and organizational culture as the normative influence of top management on employee's behaviour in the innovation process. Procedia Economics and Finance, (34), 396-402. doi: 10.1016/S2212-5671(15)01646-9

Tongsamsi, K., \& Tongsamsi, I. (2017). Instrument development for assessing knowledge management of quality assurers in Rajabhat universities, Thailand. Kasetsart Journal of Social Sciences, (38), 111-116. doi: http://dx.doi. org/10.1016/j.kjss.2016.03.005

Trivellas, P., Akrivouli, Z., Tsifora, E., \& Tsoutsa, P. (2015). The impact of knowledge sharing culture on job satisfaction in accounting firms. The mediating effect of general competencies. Procedia Economics and Finance, (19), 238-247. doi: 10.1016/S2212-5671(15)00025-8

Valmohammadi, C., \& Roshanzamir, S. (2015). The guidelines of improvement: Relations among organizational. International Journal of Production Economics, 164, 167-178. doi: http:// dx.doi.org/10.1016/j.ijpe.2014.12.028

Warrick, D. (2017). What leaders need to know about organizational culture. Business Horizons, (60), 395-404. doi: http://dx.doi.org/10.1016/j. bushor.2017.01.011

Wei, Y., \& Miraglia, S. (2017). Organizational culture and knowledge transfer in projectbased organizations: Theoretical insights from a Chinese construction firm. International Journal of Project Management, (35), 571-585. doi: http://dx.doi.org/10.1016/j.ijproman.2017.02.010 


\section{KNOWLEDGE MANAGEMENT ASSESSMENT MODEL}

The questions asked here are part of the research project, knowledge management strategies for BPO CALL CENTER Companies. Thank you for answering all the questions and for your sincerity in doing so.

Respondent: Position:

Date:

Rate from 1 to 5, where 1 disagrees or does not apply it, 3 agrees or applies and 5 fully agrees or applies.

\begin{tabular}{|l|l|l|}
\hline Question & Value
\end{tabular}

1. Do employees know how to identify available and key knowledge?

2. Have ways been developed for the generation of new knowledge (such as training or job rotation)?

3. Are there roles and responsibilities for the storage and preservation of knowledge?

4. Sharing knowledge, has a significant contribution been made to the organization?

5. Is knowledge applied to improve and innovate at work?

6. Are there hardware, software and telecommunications that support KM?

7. Are management models used such as ITMARK, CMMI, ISO, COBIT, ISO, ITIL, etc.?

8. Do you have collaborative work environments or knowledge engineering tools for KM?

9. Do staff know how to associate knowledge with business processes and activities?

10. Is dynamism emphasized and willingness to face new challenges based on KM?

11. Are there appropriate physical spaces to enable KM?

12. Are there processes that allow the formulation of strategies and scenarios from KM?

13. Are there any information and communication strategies that focus on the development of KM?

14. Are the knowledge bases for the sales exercise sought and verified?

15. Is knowledge transferred in training, publications or licensing?

16 Is financial KM used for the company's activities?

17 Are sales and market segmentation strategies formulated on the basis of KM?

18. Is there the capacity to perform competitive intelligence and surveillance in science and technology?

19. Are there legal ways and tools for KM development processes?

20. Is $\mathrm{KM}$, on, from and for stakeholders?

21. Is the management style characterized by teamwork, consensus and participation?

22. Are flexibility and curiosity fundamental to the development of processes?

23. Is it verified that communications and knowledge of others help the understanding of the messages?

24. Do teams perform KM with collaborative work networks?

\section{¿How to quote this article?}

Marulanda Echeverry, C. E., Bedoya Herrera, O. M., \& Castaño Vélez, A. P. (2019). Knowledge management from the organizational culture in call centers in Manizales. Cuadernos de Administración, 35(63), 15-25. DOI: https://doi. org/10.25100/cdea.v35i63.6811

Cuadernos de Administración journal by Universidad del Valle is under licence Creative Commons Reconocimiento-NoComercial-SinObrasDerivadas 4.0. Based in http://cuadernosdeadministracion.univalle.edu.co/ 